\title{
The influence of different moisture contents and nitrogen levels on the formation of empty cavities in cucumbers (Cucumis sativus L.)
}

\author{
KRYSTYNA ELKNER \\ Research Institute of Vegetable Crops, 22 Lipca 1/3, 96-100 Skierniewice, Poland
}

(Received: April 16, 1979)

\begin{abstract}
Empty cavities were found already in very young cucumber fruits with diameter $1.5 \mathrm{~cm}$. As the fruit develops the empty cavities augment and the number of fruits showing this defect increases. Low soil moisture and high nitrogen fertilization favour the formation of empty cavities. Their origination and changes were traced with anatomical methods in the course of fruit development. As a most plausible cause of their origination the author considers the enlargement of only part of the cells of the suture between the two (or three) carples. Due to this uneven enlargement of neighbouring cells strong mechanical tension probably arises amoung them, leading to the formation of ruptures separating these cells, consequently causing the separation of the carpel edges. Besides that, some of the cells of the suture which have markedly enlarged, often burst which also contributes to the formation of an empty cavity and enlarges its dimensions.
\end{abstract}

\section{INTRODUCTION}

The causes of why empty cavities develop in cucumbers (Fig. 1) have not been explored well enough so far, although the losses that the cucumber-pickling plants incur due to this defect are large (in Poland they amounted sometimes to $30 \%$ ).

The initial presumption was that empty cavities form because of the chemical changes occurring during the fermentation process $(\mathrm{V} \mathrm{e} \mathrm{ld} \mathrm{h} \mathrm{u} \mathrm{is} \mathrm{and}$ E t c h e $11 \mathrm{~s}, 1939 ; \mathrm{F}$ a b i a $\mathrm{n}$ and A $11 \mathrm{e} \mathrm{n,} \mathrm{1951).} \mathrm{Later} \mathrm{studies} \mathrm{showed} \mathrm{a}$ dependance between some characteristics of fresh fruits (such as size, thickness and hardness of the skin) and the formation of empty cavities in pickled fruits ( $\mathrm{J}$ o n e s et al., 1954; S n e e d and B o w e r s, 1970). This phenomenon was also considered as related to the duration of processing, retarded processing after harvest and harvest date ( $\mathrm{N} \mathrm{i} \mathrm{c} \mathrm{h} \mathrm{o} \mathrm{l} \mathrm{a} \mathrm{s} \mathrm{and} \mathrm{Pflug}$, 1962; E l k n e r, 1969). The authors of those studies also observed that the inclination of fruits to 


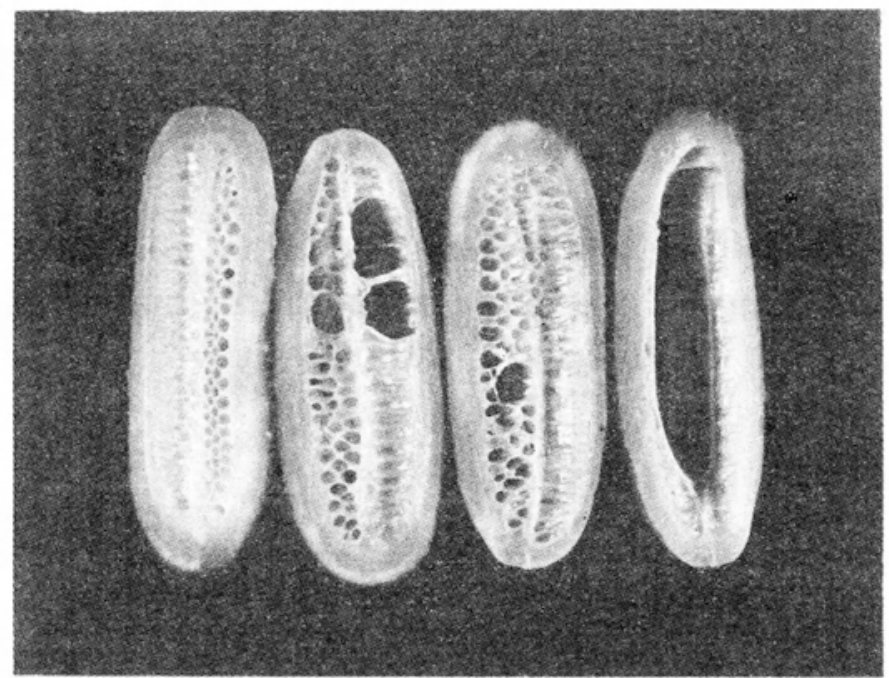

Fig. 1. Empty cavities in pickled cucumbers

develop empty cavities depends on the cultivar ( $\mathrm{W}$ i $1 \mathrm{~s} \mathrm{o} \mathrm{n}$ and $\mathrm{B}$ a k e r, 1976). The origination of empty cavities in cucumbers is also largely influenced by the conditions in which plants are grown: such as intensive mineral fertilizing and the weather. Increase of the nitrogen dose may boost the cucumber crop but also reduce its quality, leading to the formation of empty cavities ( $\mathrm{N}$ i c o 1 a i s e $\mathrm{n}$ and $\mathrm{N}$ ol t s, 1933; G a r a n i n a, 1965; E $1 \mathrm{k} \mathrm{n}$ e r, 1972). An overdose of nitrogen weakens the fruit structure, because the parenchymatous cells grow in size (B a c k e r-D i 11 i n g e n, 1956; C h r o b o c z e k, 1957; K m i ec i k, 1976). According to $\mathrm{Fa} \mathrm{j} \mathrm{k} \mathrm{ow} \mathrm{s} \mathrm{k} \mathrm{a} \mathrm{and} \mathrm{Sk} \mathrm{kodow} \mathrm{s} \mathrm{k} \mathrm{i} \mathrm{(1962)}$ the cucumber crop and its quality depends more on the weather than on the kind of fertilizer and cultivation. A long drought period or abrupt changes in temperature during the fructification period favour the development of empty cavities (K r a s ow s a, 1970; E l k n e r and R a d z i k ow s k a, 1976). During cool and wet summers the fruits contain less pectins and saccharides, a factor favouring the flaccidity of the tissues and empty cavity formation (O s i ń s k a, 1950). There are several papers striving to explain the formation of empty cavities in peaches, strawberries, melons, as well as celeries and other vegetables ( $\mathrm{R}$ e e v e, 1959; $\mathrm{N}$ e a 1, 1965; W e b s t e r, 1975; $\mathrm{H}$ a r t m a n and $\mathrm{W}$ a $1 \mathrm{~d} \mathrm{~h} \ddot{\mathrm{o}} \mathrm{r}, 1977)$. But, there have been very few papers dealing with the mechanism of empty cavity formation in the cucumber fruits, the author knows cnly one such paper, concerning the anatomic aspects of this mechanism (M i lle r and M or e y 1977).

The purpose of this study was to trace the course of empty cavity formation in cucumber fruit by anatomic investigation in plant groups growing in the conditions of different moisture content and nitrogen level in the soil. 


\section{MATERIAL AND METHODS}

The material for the anatomic investigations was supplied from a greenhouse experiment set up expressly for this purpose: In the experiment, cucumbers of the 'Monastyrski' variety were cultivated in the podsolic soil developed from sand formations on boulder-clay and having the following mechanical composition: $58 \%$ sand fraction, $27 \%$ dust fraction and $15 \%$ loamy fraction. During the vegetation, the nitrogen content in the soil was maintained at the level of $100 \mathrm{mg} / \mathrm{l}$ or $300 \mathrm{mg} / \mathrm{l}$, using ammonium nitrate, according to the results of soil sample analysis ( $\mathrm{N} \mathrm{o} \mathrm{w} \mathrm{o} \mathrm{s} \mathrm{i} \mathrm{e} 1 \mathrm{~s} \mathrm{k} \mathrm{i}, 1968$ ). The content of the other mineral ingredients in the soil amounted to (in $\mathrm{mg} / \mathrm{l}$ ): $\mathrm{P}-160, \mathrm{~K}-200, \mathrm{Ca}-1600, \mathrm{Mg}-$ 110. The soil $\mathrm{pH}$ was 6.7 .

Initially the moisture content was maintained at the level of about $70 \%$ fwc (field water capacity), corresponding to $0.4 \mathrm{~atm}$, whereas from April it was divided into two levels: $65 \%$ fwc $(0.35 \mathrm{~atm})$ and $85 \%$ fwc $(0.2 \mathrm{~atm})$.

The schedule of plant watering was established on the basis of tensiometer indications.

The pattern of the experiment was as follows:

$\begin{array}{ll}100 \mathrm{mg} / 1 \mathrm{~N}+85 \% \text { fwc } & 300 \mathrm{mg} / \mathrm{l}+85 \% \text { fwc } \\ 100 \mathrm{mg} / 1 \mathrm{~N}+65 \% \text { fwc } & 300 \mathrm{mg} / 1 \mathrm{~N}+65 \% \text { fwc }\end{array}$

The observations and measurements of anatomical characters were made in the samples taken from the fruits within 3, 6,9 and 12 days of the (manual) pollination. Each sample series was made up of 4 cucumbers taken from every growth stage mentioned here. The tissue fragments were embedded in paraffin. The cross sections were taken at the mid-length of the fruit, as well as from the apical part at the place where carples were already formed.

The microscopic observations concerned:

(a) fragments of folded edges of the carpel (sutures), (spots, nearest to the exocarp).

(b) fragments of the ovary where the three carpels meet. The paraffin slides, 12 $\mu \mathrm{m}$ thick. were dyed with alkaline fuchsin blended with intense green FCF (F i l u l ow i c z and $\mathrm{K} \mathrm{u} z \mathrm{~d}$ ow ic , 1951). The slide inspection and photographing was carried out by means of a NU 1 Zeiss microscope. Moreover, every fruit was subjected to 20 measurements of the cell length along the internal carpels suture. 20 fruits were taken from every combination for longitudinai sections to establish the percentage of the fruits with empty cavities.

\section{RESULTS AND DISCUSSION}

There is a characteristic pattern of three carpels in the endocarp of the cucumber. Prior to the pollination the carpels are partly separeted by fissures (Plate I: 1,2). Shortly after the pollination the fissures disappear as the epedermis 


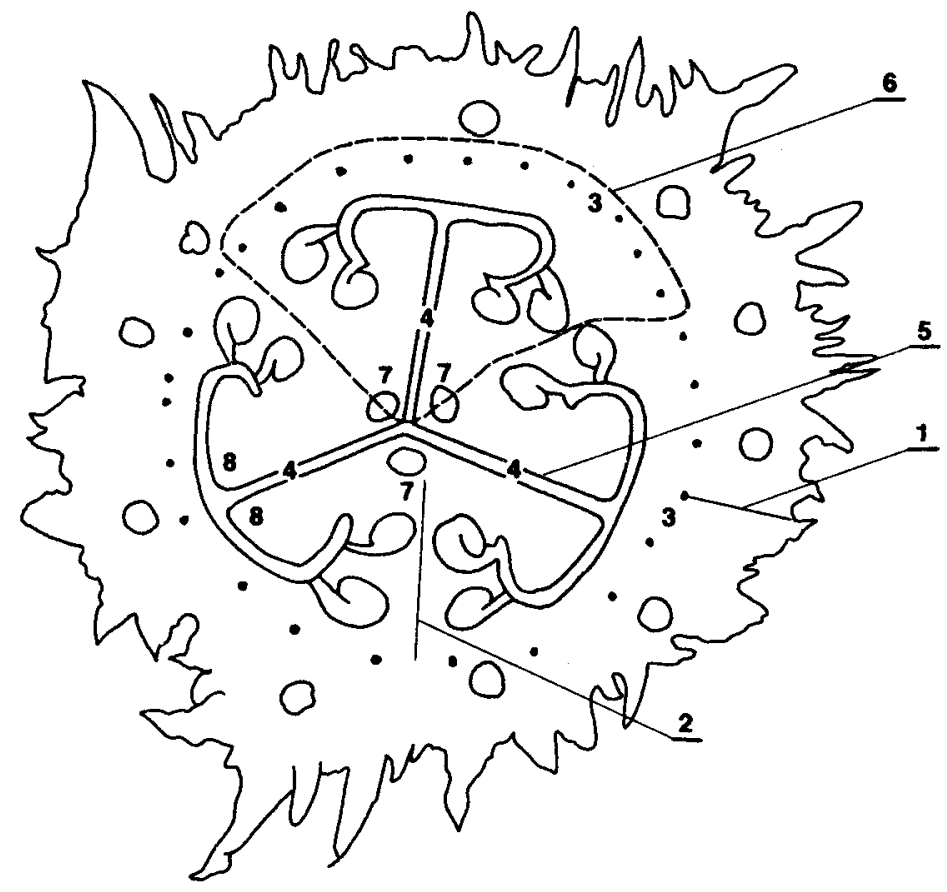

Fig. 2. Section of the central part of the young cucumber fruit: 1 - exocarp; 2 - endocarp (surrounding seeds); 3 - vascular bundles on the border line between the exocarp and the endocarp; 4 - the region where the folded carpel edges grown into together; 5 - ovary center (region where three carpels meet); 6 - the region of one carpel (stroke); 7 - central vascular boundles; 8 placentae

of the neighbouring carpels seal, leaving the characteristic T-shaped sutures (Fig. 2, Plate I: 3).

At the flexures of the suture there are the points of seed attachement (Plate II: 4). The cells of sutures aligned in a double row are small, have large nuclei and large amount of cytoplasm (Plate I: 3).

The formation of empty cavities in cucumber fruits is mainly related to the disjunction of carpel edges, which is compatible with the microscopic observations made by $\mathrm{H}$ o o p e r et al.(1972), as well as $\mathrm{W}$ i $1 \mathrm{~s} \mathrm{o} \mathrm{n}$ and $\mathrm{B}$ a k e r (1976).

The research presented here has shown a phenomenon preceding the formation of empty cavities, namely the appearance, along some sections of one of the two adjoining surfaces (edges) of carples, of small groups of cells several times larger then the cells on the opposite surface (edge). At the next stage it was found that the surfaces separated from one another and the "large" cells disintegrated. As a results of these phenomena the empty space appeared (Fig. 3).

The fruits from plants grown in the soil conditions in which a strong tendency to form empty cavities was observed (Table 2), showed larger suture cells at all 

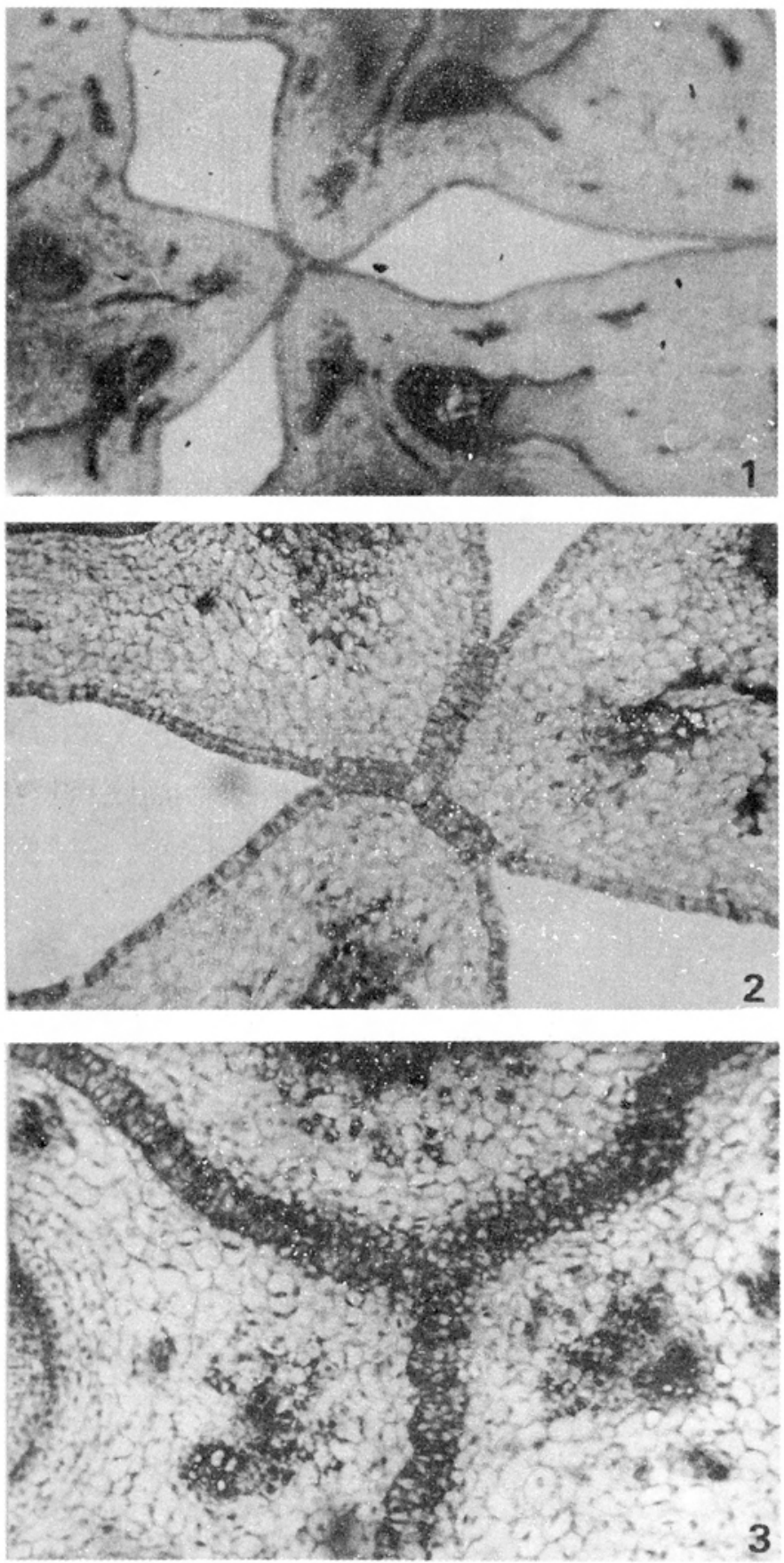

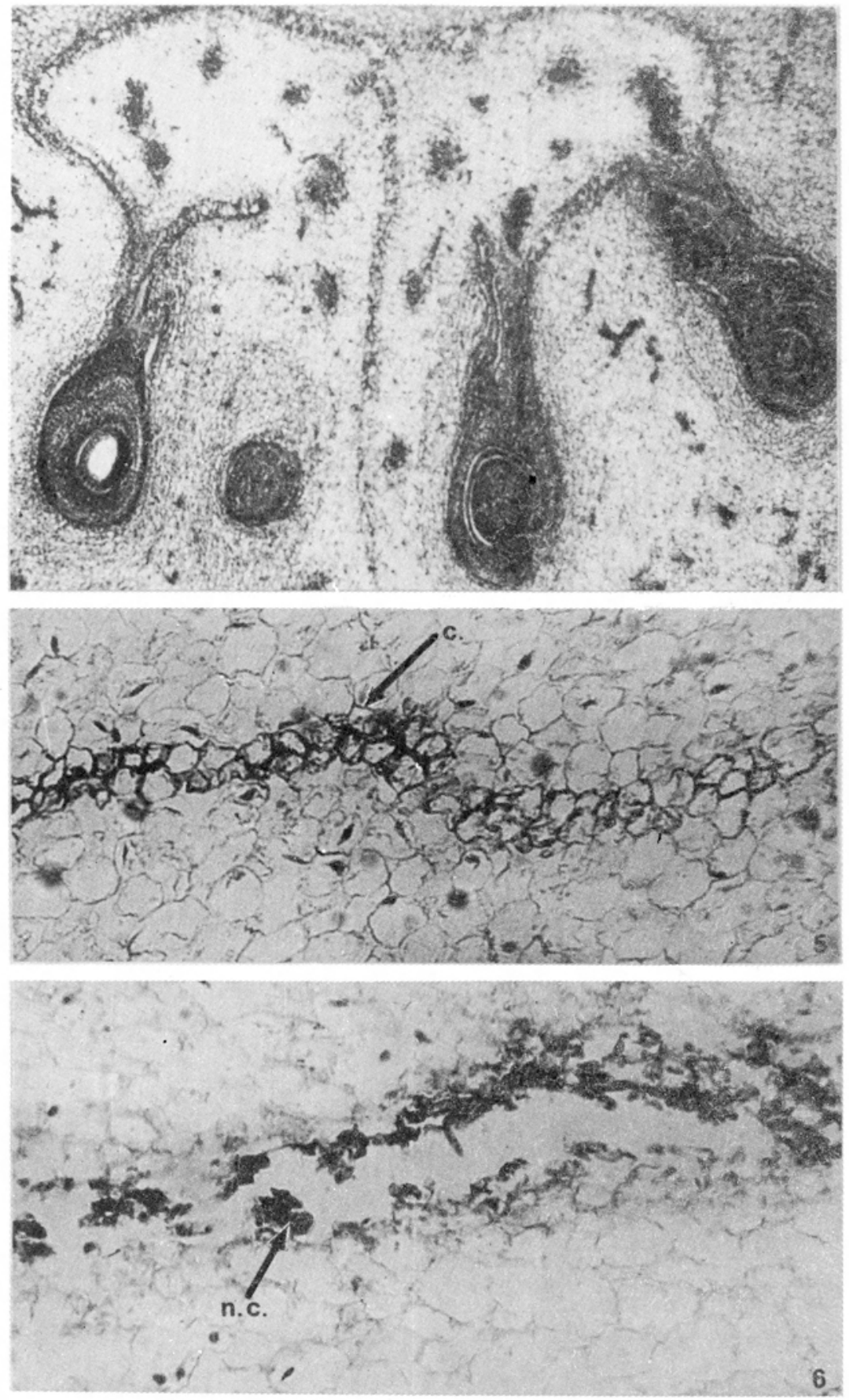

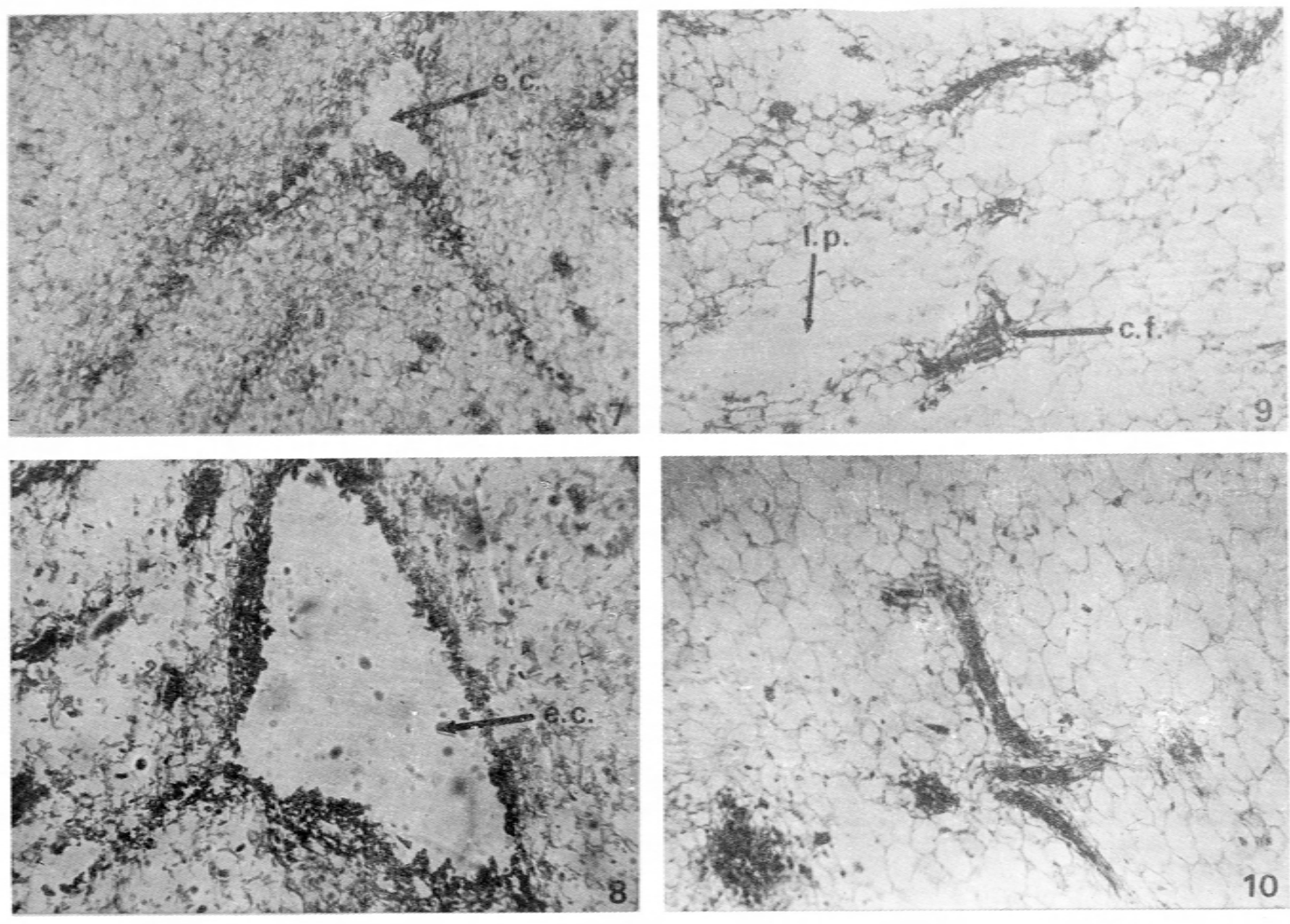


\section{Plate I}

1. Cross section of a young ovary (prior to pollination). The carpels have not sealed yet. $(\times 170)$

2. The central part of the ovary where three carples come together (period prior to pollination). Fragment of Fig. 2. $(\times 250)$

3. The spot where three carpels seal in the ovary center after pollination (compare Plate I: 2$).(\times 250)$

\section{P l a t e II}

4. Folded edges of carpel - place of seeds attachment (compare Plate I: 2$).(\times 250)$

5. A fragment of the carpel (c.) edge cells. (A 6-day fruit from the soil conditions marked by a lower nitrogen content and a low moisture content $-100 \mathrm{mg} / \mathrm{l} \mathrm{N}+65 \% \mathrm{fwc}) .(\times 250)$

6. Necrotic concentrations (n.c.) along the separated edges of carpel (12-day fruit the soil conditions markedly having a lower nitrogen and a low moisture content $-100 \mathrm{mg} / 1 \mathrm{~N}+65 \%$ fwc $).(\times 250)$

\section{P l a t e III}

7. Formation of an empty cavity (e.c.) in the cucumber fruit at the spot where the carpel edges seal on the borderline of the exo- and endocarp (6-day fruit from the soil containing more nitrogen and little moisture $-300 \mathrm{mg} / 1 \mathrm{~N}+65 \%$ fwc). $(\times 250)$

8. A fragment of the separated carpel edges on the borderline of exo- and endocarp (12-day fruit from the soil having a high nitrogen content and a low moisture content $300 \mathrm{mg} / \mathrm{l} \mathrm{N}+65 \% \mathrm{fwc}) .(\times 250)$ 9. Disintegration of the parenchymatic cells (l.p.) in vicinity of vascular boundles (c.f.). (6-day fruit from soil marked by a high nitrogen content and a low moisture content $-300 \mathrm{mg} / \mathrm{l} \mathrm{N}+65 \% \mathrm{fwc}$ ).

$$
(\times 250)
$$

10. A fragment of the endocarp with vascular bundles (12-day fruit from soil containing less nitrogen and more moisture $-100 \mathrm{mg} / 1 \mathrm{~N}+85 \%$ fwc $).(\times 250)$ 


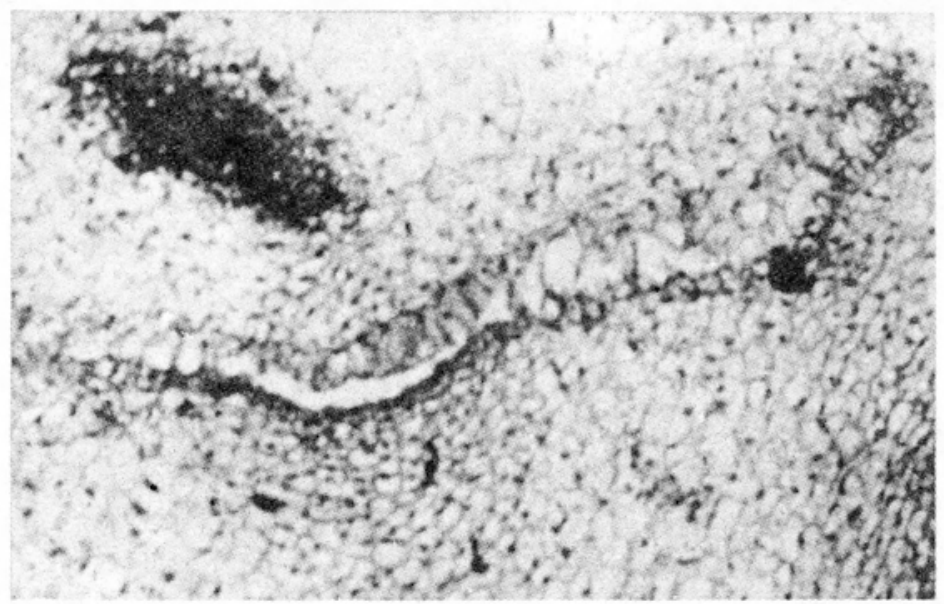

Fig. 3. The process in which the sealed carpel edges (forming suture) disjoin. The cells of only one of the two edges have markedly enlarged which is considered as a cause of the inception of empty space. Some cells have burst. Suture cells are marked by thicker lines. (A 3-day fruit from the soil pattern marked by a high nitrogen content and a low moisture content $-300 \mathrm{mg} / \mathrm{l} \mathrm{N}+65 \%$ fwc)

stages of their development (the average size of cells on both sides of the suture was taken), (Table 1). Their cell walls absorbed the dye more intensively and were, therefore, more distinct at the cross section and formed more uneven double lines (Plate II: 5). With the progress of the growth, the walls of large cells break to begin forming an empty cavity. In effect of the burst of walls of the large cells adjoining to an empty cavity, necrotic concretions develop (Plate II: 6).

T a b I e 1

The average size of epidermal cells $(\mu \mathrm{m})$ located along the internal suture of the carpels, depending on different moisture and nitrogen content in the soil

\begin{tabular}{cccccc}
\hline \multirow{2}{*}{$\begin{array}{c}\text { Nitrogen } \\
\text { content } \\
(\mathrm{mg} / \mathrm{l} \text { of soil) }\end{array}$} & $\begin{array}{c}\text { Moisture } \\
\text { content } \\
(\% \text { fwc) }\end{array}$ & \multicolumn{4}{c}{$\begin{array}{c}\text { Average size of suture cells in } \\
\text { fruit carpels }\end{array}$} \\
\cline { 3 - 6 } & & 3-day & 6-day & 9-day & 12-day \\
\hline \multirow{2}{*}{100} & 85 & 17.15 & 19.74 & 23.50 & 25.30 \\
& 65 & 18.60 & 21.70 & 34.10 & 39.45 \\
300 & 85 & 18.03 & 20.55 & 24.02 & 26.92 \\
& 65 & 18.60 & 24.80 & 39.20 & 47.54 \\
\hline
\end{tabular}

The cells along the edge of the carpel suture initially adhere to each other. In the case of the fruits which tend to develop empty spaces, the cells located along the suture grow unevenly and begin to differ in size - this inevitably must lead to the appearance of mechanical tension between them and in consequence 


\section{Ta b 1 e 2}

The occurrence of empty cavities in cucumber fruits (\%) depending on the differentiated moisture and nitrogen content in the soil

\begin{tabular}{ccccc}
\hline & & \multicolumn{3}{c}{$\begin{array}{c}\text { Percentage of cucumbers with } \\
\text { empty cavities in their fruits }\end{array}$} \\
\cline { 3 - 5 } $\begin{array}{c}\text { Nitrogen } \\
\text { content } \\
(\mathrm{mg} / \text { of soil) }\end{array}$ & $\begin{array}{c}\text { Moisture } \\
\text { content } \\
(\% \text { fwc) }\end{array}$ & 6-day & 9-day & 12-day \\
\cline { 3 - 5 } & & \multicolumn{3}{c}{ diameter in cm } \\
\cline { 3 - 5 } & 85 & 1.0 & 2.5 & 7.5 \\
\hline \multirow{2}{*}{100} & 65 & 5.0 & 20.5 & 40.0 \\
& 85 & 2.5 & 10.0 & 27.5 \\
300 & 65 & 10.0 & 30.0 & 57.5 \\
\hline
\end{tabular}

probably causes their separation. Similar phenomena occur at the abscission layer between the fruit and the stem, or between the leaf and the stem in some other plants (W e b s t e r, 1975; J a n k i e w i c z, 1979).

Maturation was a factor affecting the formation of empty cavities in cucumber fruits. With the fruit growth, the empty cavities enlarge and the number of cucumbers showing this defect increases (Plate III: 7, 8, Table 2). The separation of the cells along the carpel suture was observable through the microscope already in fruits with a diameter of $1 \mathrm{~cm}$, and with the naked eye - in fruits with a diameter of $1.5 \mathrm{~cm}$. These observations do not correspond fully to those made by $\mathrm{M}$ i $11 \mathrm{e} \mathrm{r}$ and $M$ or e y (1977). According to them, empty cavities become visible only in fruits with a diameter of $4 \mathrm{~cm}$. These researches, however, studied varieties marked by the exceptionally weak tendency to develop empty cavities. The present investigations, on the other hand, were done on cucumbers of the 'Monastyrski' cultivar prone to shaw this defect. Empty cavities in celeries also develop when the swellings are small and enlarge as the latter grow ( $\mathrm{H}$ a $\mathrm{r} \mathrm{m}$ a $\mathrm{n}$ and $\mathrm{W}$ a $1 \mathrm{t} \mathrm{h}$ ö r, 1977). The observed enlargement of empty cavities in cucumbers with their growth and maturing can be attributed to the progressing, natural disintegration of the middle lamellae and a depletion of the pectins. The disintegration of the middle lamellae and a decrease in the amount of pectins has also been noted in the ripening melon fruits (W e b s t e r, 1975), strawberries ( $N$ e a 1,1965$)$ and peaches ( $R$ e e v e, 1959). Disjunction of the carpel suture edges occurs more strongly in the conditions of a low moisture content $(65 \% \mathrm{fwc})$ and a high nitrogen content in the soil (Table 2$)$.

The measurements indicate that the average size of the cells aligned along the carpel sutures is positively correlated with the tendency to develop empty cavities. The largest suture cells $-47.5 \mu \mathrm{m}$ (average of the cells arrayes along both edges of the suture) were found in fruits grown in the soil conditions marked 
by a high nitrogen content and a low moisture content $(300 \mathrm{mg} / 1 \mathrm{~N}+85 \%$ fwc) (Table 1). The plants grown in these soil conditions produced $57.5 \%$ of the fruits with empty cavities (Table 2). The fruits grown in the soil conditions marked by a lower nitrogen content and a high moisture level $(100 \mathrm{mg} / \mathrm{l} \mathrm{N}+85 \%$ fwc) showed the least average diameter of the suture cells $(25.3 \mu \mathrm{m})$, (Table 1$)$ and simultaneously the smallest percentage of cucumbers affected by this defect $7.5 \%$, (Table 2). It can be presumed that in plants which are short of moisture there occur periods during the day when young leaves and shoot tips compete for moisture against fruits ( $\mathrm{M} \mathrm{i} \mathrm{c} \mathrm{h} \mathrm{n} \mathrm{i} \mathrm{e} \mathrm{w} \mathrm{i} \mathrm{c} \mathrm{z,} \mathrm{1977).} \mathrm{This} \mathrm{may} \mathrm{cause} \mathrm{large}$ diurnal oscilations of the fruit turgor which favours the rupture of the contact between cells and bursting of the large cells. Moreover, it was found that the fruits of the plants intensively fertilized with nitrogen $(300 \mathrm{mg} / \mathrm{l} \mathrm{N})$ at a low moisture content in the soil $(65 \%$ fwc) show a specific type of empty cavities: the endocarp parenchyma cells disintegrate in the neighborhood of vascular bundels (Plate III: 9). Small cells adjoining vascular bundels were undergoing changes: their protoplast were shrinking as during the plasmolysis. On the other hand, larger cells with big vacuoles burst, producing gaps in the parenchyma. The fruits grown in the soil conditions marked by a higher moisture content showed no gaps in the parenchyma in vicinity of vasculor tissues (Plate III: 10).

\section{Acknowledgements}

I am indebted to my advisor Professor H. Skapski, as well as to Prof. L. S. Jankiewicz for their kind assistance. I am also grateful to B. Dyki, M. Sc., for anatomic photos and to Dr. J. Bakkowski for providing good conditions for conducting these experiments.

\section{REFERENCES}

B a c k e r-D i 11 i n g e n J., 1956. Handbuch des gesamten Gemüsebaus. Paul Parey, Berlin.

$\mathrm{C}$ h r o b o c z e k E., 1957. Zagadnienia produkcji surowca warzywnego dla przetwórstwa. Zesz. nauk. SGGW, Ogrod. 1: 23-26.

E 1 k n e r K., 1969. Wpływ świeżości surowca na jakość kwaszonych ogórków. Ogrodnictwo, 6: $170-173$.

E 1 k n e r K., 1972. Wplyw nawożenia na jakość kwaszonych ogórków. Biul. warz. 13: 86-95.

E $1 \mathrm{k} n$ e r K., $\mathrm{R}$ a d z i k ow s k a D., 1976. Wpływ nawadniania, nawożenia mineralnego i odmiany na jakość ogórków przeznaczonych do kwaszenia. Zesz. probl. Postęp. Nauk. rol. 181: $55-70$.

F a b i a n F., A 11 e n O., 1951. Aerobacter aerogenes as a cause of ropy brine in cucumber fermentation. Food Res. 5.

F a j k o w s k a H., S k ł o d o w s k i P., 1962. Wpływ nawożenia i płodozmianu na plony 6 roślin warzywnych: a) pomidor, por, fasola szparagowa, b) ogórek, cykoria, groch w latach 1952-1960. Biul. warz. 6: 137-148.

F i l u t ow i c z A., K u ż d o w i c z A., 1951. Mikrotecnnıka roślinna. PWRiL, Warszawa.

G a r a n in a N., 1965. Vliyanie udobrenı na urozhai ogurtsov i kachestvo solennoi produkcı. Kons. Ovoshch. Prom: 1: 23-25.

H a r $t$ m a n D. H., W a I d h ö r O., 1977. Napfbildung bei Knollensellerie (Apium grateolens L.) II Einfluss des Wasserhaushaltes. Gartenbauwiss. 2: 55-58. 
H o o per A. W., B a ke r D. E., M a r s h 11 D. E., H e l d m a n D. R., 1972. Determination of force required to separate carpels of cucumber fruit slices. Hort. Sci. 7: 336-337 (Abstr.).

J a $\mathbf{n}$ k i e w i c z L. S., 1979. Okresy życiowe organizmu roślinnego i jego części. [In:] L. S. Jankiewicz (ed). Fiziologia roślin sadowniczych, PWN, Warszawa.

J o n e s I. D., E t c h e $11 \mathrm{~s}$ J. L., M o n r o e R. J., 1954. Varietal differences in cucumber for pickling. Food Technology, 8: 415-418.

K m i e c i k W., 1976. Wplyw poziomu nawożenia azotem na wysokość i jakość plonów ogórka oraz jego przydatność do konserwowania i kwaszenia. Habilitation thesis, Agricultural University, Kraków.

K r a s s o w s k a J., 1970. Przydatność odmian ogórków dla kwaszarnictwa. IPDiRz, Warszawa.

M i chn i e wi c z A., 1977. Odporność roślin na niesprzyjające czynniki środowiska. [In:] Zurzycki J., Michniewicz M., (eds). Fizjologia roślin, PWN, Warszawa.

M i l l e r J., M or e y P. R., 197.7. Anatomical differences associated with inherent carpel separation along ventral sutures in pickling cucumber. J. Amer. Soc. Hort. Sci. 102 (4): 410-413.

$\mathrm{N}$ e a 1 G. E., 1965. Changes occurring in the cell walls of strawberries during ripening. J. Sci. Food Agric. 16: 604-610.

$\mathrm{N}$ i c h o l a s R. G., P f I u g I. J, 1962. Variety response to some variables in fresh cucumber pickle production. Mich. Agr. Exp. Sta. Quart. Bull. 44: 739-750.

N i c o 1 a i s e n N., N o 1 t e O., 1933. Der Einfluss sachgemässer Düngung auf Ertrag und Güte von Gurken. Berlin.

N o w o s i e 1 s k i O., 1968. Nawożenie roślin warzywnych. PWRiL, Warszawa.

O s i ń s k a J., 1950. Ogórki kiszone. PWT, Warszawa.

R e e v e R. M., 1959. Histological and histochemical changes in developing and ripening 11 . The cell walls and pectins. Amer. J. Bot. 46: 241-248.

S n e e d F. D., B o w e r s J. L., 1970. Green fruit characters of cucumber as related to quality factors in brine stoc. J. Amer. Soc. Hort. 95 (4): 489-491.

W e b s t e r B. D., 1975. Anatomical and histochemical modifications associated with abscission of cucumis fruits. J. Amer. Soc. Hort. Sci. 100 (2): 180-184.

W i 1 s o n J. E., B a k e r L. R., 1976. Inheritance of carpel separation in mature fruits of pickling cucumbers. J. Amer. Soc. Hort. Sci. 101: 66-69.

$\mathrm{V}$ e $1 \mathrm{~d}$ h u is M. K., E t c h e ll s J. L. 1939. Gazeous products of cucumber pickle fermentations. Food Res. 4: 621-630.

\section{Wpływ zróżnicowanej wilgotności i poziomu azotu w glebie na przebieg powstawania pustych komór w owocach ogórka (Cucumis sativus L.)}

\section{Streszczenie}

Powstawanie pustych komór w owocach ogórka spowodowane jest silnym powiększeniem się niektórych komórek brzegów owocolistków. W następstwie nierównomiernego powiększania się sąsiadujących ze sobą komórek powstają między nimi prawdopodobnie napięcia mechaniczne, prowadzące do oddzielania się od siebie brzegów owocolistków i wytworzenia pustej komory. Poza tym wytworzone duże komórki rozpadają się i tworzy się pusty kanal (komora) często na całej długości owocu. Puste komory stwierdzono już w owocach o średnicy $1,5 \mathrm{~cm}$. W miarę wzrostu i dojrzewania owoców puste komory powiększają się i wzrasta liczba ogórków z tą wadą. Czynnikami sprzyjającymi oddzielaniu się brzegów szwu owocolistków jest niska wilgotność gleby i wysokie nawożenie azotowe. 